\title{
Effect of monensin on the fermentation of basal rations in the Rumen Simulation Technique (Rusitec)
}

\author{
BY R. J. WALLACE \\ The Rowett Research Institute, Bucksburn, Aberdeen AB2 9SB
}

AND J. W. CZERKAWSKI AND GRACE BRECKENRIDGE

The Hannah Research Institute, Ayr, Scotland KA6 5HL

(Received 3 November 1980 - Accepted 25 February 1981)

\begin{abstract}
1. A long-term experiment was made with the Rumen Simulation Technique (Rusitec), in which the fermentation of a mixed ration of hay $(10 \mathrm{~g} / \mathrm{d})$ and bruised barley $(5 \mathrm{~g} / \mathrm{d})$ was compared with the fermentation of the same diet in the presence of 2,10 and $50 \mathrm{mg}$ monensin/d.

2. Monensin depressed the prcduction of acetic and butyric acids, markedly increased the production of propionic acid and virtually eliminated the production of isovaleric acid. The production of methane was decreased in the presence of monensin, but tins decrease could be accounted for entirely by the changes in the production of volatile fatty acids and redistritiution of metabolic hydrogen.

3. The digestibility of dry matter (DM) in the rations declined in the presence of monensin. Determinations of the rates of digestion showed that the digestion of the readily-fermented food in the initial stages was not affected by monensin, but that at $24 \mathrm{~h}$ digestion had been inhibited by monensin. The inhibition was due entirely to its effect on the digestion of the fibrous components. Digestion of non-fibrous material was not affected.

4. The efficiency of microbial growth, expressed as g dry weight/mol ATP formed $\left(Y_{\text {ATP }}\right)$ and in terms of DM digested, tended to be increased by monensin. This however occurred only at high, non-practical doses.

5. Urease $(E C$ 3.5.1.5) was incluced by the addition of urea to the fermentation, but monensin had no effect on urease activity. Although monen sin increased the activity of protease in washed suspensions, more food protein apparently escaped degradation. This may have been due to decreased deaminative activity.

6. Monensin altered the mircroszopic appearance of the fermentation fluid, and changed the activity of some enzymes in sonicated extracts, including alkaline phosphatase $(E C$ 3.1.3.1), acetate kinase $(E C 2.7 .2 .1)$ and succinate dehydrogenase (EC 1.3.99.1). These results are discussed in terms of known sensitivities of rumen microbes to monensin and their contribution to the fermentation as a whole.
\end{abstract}

Monensin is an antibiotic which, when incorporated with many kinds of ruminant foodstuff, reportedly increases the efficiency of food conversion. An increased molar proportion of propionate in volatile fatty acids (VFA) in the rumen and decreased methanogenesis (Thornton et al. 1976; Jouariy \& Senaud, 1978; Chalupa et al. 1980) are usually associated with monensin supplementation and so improved performance would be expected on the basis of improved retention of carbon and energy in the rumen fermentation (Hungate, 1966; Richardson et al. 1976). Furthermore, if, as proposed by Blaxter \& Wainman (1964), propionate is more efficiently utilized by the host animal than acetate, then the altered stoichiometry caused by monensin would be additionally beneficial. More recent results, however, suggest that this is unlikely (Ørskov et al. 1979). It is not clear which of the other reported consequences of monensin supplementation stem directly from these changes and which are independent effects. For example, monensin is known also to be protein-sparing (Dartt et al. 1978; Hanson \& Klopfenstein, 1979; Joyner et al. 1979) but there is some doubt whether this is due mainly to the sparing of glucogenic amino acids from gluconeogenesis by the increased propionate production (Leng et al. 1967) or to direct effects on rumen proteolysis and deamination (Van Nevel \& Demeyer, 1977; Chalupa, 1980; Chalupa et al. 1980) which would lead to increased passage of dietary amino acids to the abomasum. Similarly, it is difficult to say how changes in rates of degradation (Lemenager et al. 1978), 
rumen turnover rates (Lemenager et al. 1978; Allen \& Harrison, 1979) and food intake (Raun et al. 1976; Joyner et al. 1979) are related in cause and effect. Some of the effects of monensin may indeed not be due to its effect on the rumen. Improved food efficiency can result through the control by monensin of coccidial infection in the hind-gut (Fitzgerald \& Mansfield, 1978) and reduced intake may even be partly a flavour aversion effect (Baile et al. 1979).

The Rumen Simulation Technique (Rusitec), a laboratory device successfully used for the long-term simulation of the rumen fermentation (Czerkawski \& Breckenridge, 1977), enables study of the effects of agents such as monensin free from the influence of the host animal. It has the advantage over some other in vitro incubations (e.g. Richardson et al. 1976; Van Nevel \& Demeyer, 1977; Chalupa et al. 1980) that a stable fermentation can be maintained on a time-scale sufficient to allow microbial adaptation of the type seen by Chen \& Wolin (1979) and possible longer-term adaptation which might occur over a feeding period of several weeks. It also enables the use of monensin at doses potentially toxic to the ruminant animal.

Some of the short-term effects of monensin on the fermentation in Rusitec have been reported elsewhere (Wallace et al. 1980). Some longer-term effects have been described recently by Stanier \& Davies (1981).

\section{EXPERIMENTAL \\ Materials and methods}

Inoculum. The rumen contents to be used as inocula were obtained from two sheep that were given a diet of bruised barley and hay $(300$ and $600 \mathrm{~g} / \mathrm{d}$ ) for approximately 3 weeks before the start of the experiment in vitro. The liquid samples of rumen contents were taken through the fistula by suction and the samples of solid digesta were removed with tongs.

Materials. Monensin was a crystalline preparation, kindly provided by Lilly Research Centre, Windlesham, Surrey. Azocasein, phosphatase substrate, INT [2-(p-iodophenyl)-3-pnitrophenyl-5-phenyltetrazolium chloride] and acetyl phosphate were obtained from Sigma Chemical Co. Ltd, Poole, Dorset BH17 7NH. Analar reagents were used in most other analyses, but the artificial saliva (McDougall, 1948) was prepared with tap water.

Apparatus. Rusitec as described by Czerkawski \& Breckenridge (1977) was used. The nominal volume up to overflow in each of the four vessels was $840 \mathrm{ml}$ and the nominal dilution rates in vessels nos. 1, 2, 3 and 4 were $0 \cdot 88,0 \cdot 89,0.87$ and $0.90 / \mathrm{d}$ respectively. Each vessel was supplied daily with $10 \mathrm{~g}$ chopped hay and $5 \mathrm{~g}$ bruised barley $(13.06 \mathrm{~g}$ dry matter (DM)/d). The food was provided in nylon bags which were agitated gently in the liquid phase. Two bags were present at any time and one bag was replaced each day to give $48 \mathrm{~h}$ incubation.

Rate of digestion. In order to compare rates of digestion of substrate, in addition to the routine determination of digestibility after $48 \mathrm{~h}$ incubation, smaller $(85 \times 45 \mathrm{~mm})$ nylon bags containing $2.5 \mathrm{~g}$ hay and $1.0 \mathrm{~g}$ bruised barley were tied to the two larger bags in the apparatus. While these bags were being removed, the gas dead space was flushed with carbon dioxide-nitrogen $(5: 95, \mathrm{v} / \mathrm{v})$ and the collection vessel was closed off. The mesh of the small bags (three perforations $/ \mathrm{mm}$ ) was finer than that of the large bags (one perforation $/ \mathrm{mm}$ ).

Analytical methods. Most of the routine analytical methods have been described in earlier work (Czerkawski \& Breckenridge, 1977, 1979 $a, b$ ). Microbial numbers were estimated by direct counts (Czerkawski et al. 1975).

Urease (EC 3.5.1.5) was measured by the production of ammonia from urea (Cook, 1976) using samples removed directly from Rusitec. Other enzyme activities were measured in samples which had been frozen rapidly in liquid $\mathrm{N}_{2}$ and stored at $-20^{\circ}$ or $-60^{\circ}$. Protease 
was measured essentially by the azocasein method of Dinsdale $e t$ al. (1980). The suspension was centrifuged $\left(20000 \mathrm{~g} .4^{\circ}, 15 \mathrm{~min}\right)$, the pellet was resuspended in $50 \mathrm{~mm}$-potassium dihydrogen phosphate $\mathrm{pH} 7.5$ and this suspension was incubated with an equal volume of azocasein $(2 \mathrm{~g} / \mathrm{l})$ for $5 \mathrm{~h}$ at $38^{\circ}$. The reaction was stopped by addition of trichloracetic acid to a final concentration of $50 \mathrm{~g} / \mathrm{l}$ and the undigested azocasein was removed by centrifugation $\left(31000 \mathrm{~g}, 4^{\circ}, 10 \mathrm{~min}\right)$. A portion of supernatant fluid was mixed with an equal volume of $0.5 \mathrm{M}$-sodium hydroxide and the absorbance of solubilized azocasein was measured at $440 \mathrm{~nm}$. Alkaline phophalase (EC 3.1.3.1), succinate dehydrogenase (EC 1.3.99.1), acetate kinase $(E C 2.7 .2 .1)$ and NAD- and NADP-linked glutamate dehydrogenases $(E C$ 1.4.1.2 and $E C$ 1.4.1.4) were measured on cell-free extracts prepared by sonication and centrifugation (Wallace, 1979). Alkaline phosphatase was measured by a continuous method, in which the release of $p$-nitrophenol from $p$-nitrophenyl phosphate at $25^{\circ}$ was followed at $405 \mathrm{~nm}$ in a reaction mixture containing $0 \cdot 1 \mathrm{M}$-glycine, $1 \mathrm{~mm}$-magnesium chloride, $0 \cdot 1 \mathrm{~mm}$-zinc chlcride and $6 \mathrm{~mm}$-p-nitrophenyl phosphate, $\mathrm{pH} 10 \cdot 5$. Succinate dehydrogenase was assayed by the reduction of INT (Baldwin \& Palmquist, 1965), acetate kinase by acetyl phosphate production (Rose et al. 1954) and the glutamate dehydrogenases by the oxidation of reduced pyridine nucleotides (Wallace, 1979).

\section{Experimental procedure}

The experiment was planned to last for sufficient time to allow for any possible adaptation to monensin (4 weeks) and to include a period of 1 week during which the rate of digestion of food could be measured without disturbing the system. The duration of the whole experiment was $42 \mathrm{~d}$ and for the purpose of bulking of samples and more efficient analyses the whole was divided into nine periods. During the initial control period (days 1-6) all four vessels received the sane treatment.

The administration of urea and monensin began on day 7 and continued to the end of the experiment. Part of the urea supplement was infused with artificial saliva by dissolving $1.0 \mathrm{~g}$ urea in 41 . This resulted in daily addition of $170,172,168$ and $173 \mathrm{mg}$ urea in vessels nos. 1, 2, 3 and 4 respectively. Some solid urea was also added with food $(50 \mathrm{mg} / \mathrm{d})$. This was added as such to vessel no. 1 or ground with monensin to provide $50 \mathrm{mg}$ urea and 2 , 10 and $50 \mathrm{mg}$ monensin/d in vessels nos. 2, 3 and 4 respectively. Thus, each vessel received approximately $220 \mathrm{mg}$ urea and $0-50 \mathrm{mg}$ monensin.

The treatment period (days 7-42) was divided into eight smaller periods (day of treatment in parentheses): 1(9-12), 2(13-16), 3(17-20), 4(21-24), 5(25-28), 6(29-33), 7(34-37) and $8(38-41)$. On the last day of the experiment (day 42), most of the reaction mixtures, washings and undigested residues were frozen rapidly in liquid $\mathrm{N}_{2}$ and stored at $-20^{\circ}$. Rates of digestion were measured during period 5.

\section{RESULTS}

\section{Effect of monensin on digestion of basal rations}

The digestibility of DM after $48 \mathrm{~h}$ incubation in each vessel was determined daily, and the means of consecutive 4-5d periods were calculated. Monensin caused an immediate fall in the digestibility of DM, with the highest dose producing the greatest effect (Fig. 1). The decreased DM digestibility persisted for the duration of the experiment, without appreciable drift (Fig. 1). On day 20, a small quantity of monensin (approximately $8 \mathrm{mg}$ ) was accidentally added to vessel no. 1 , so the digestibility in vessel no. 1 for this period was unusually low (Fig. 1). Analysis of the undigested residues showed that monensin had no effect on the digestion of non-fibrous components of the food, and that the depressed digestibility of DM was due entirely to decreased digestion of cellulose and hemicellulose 


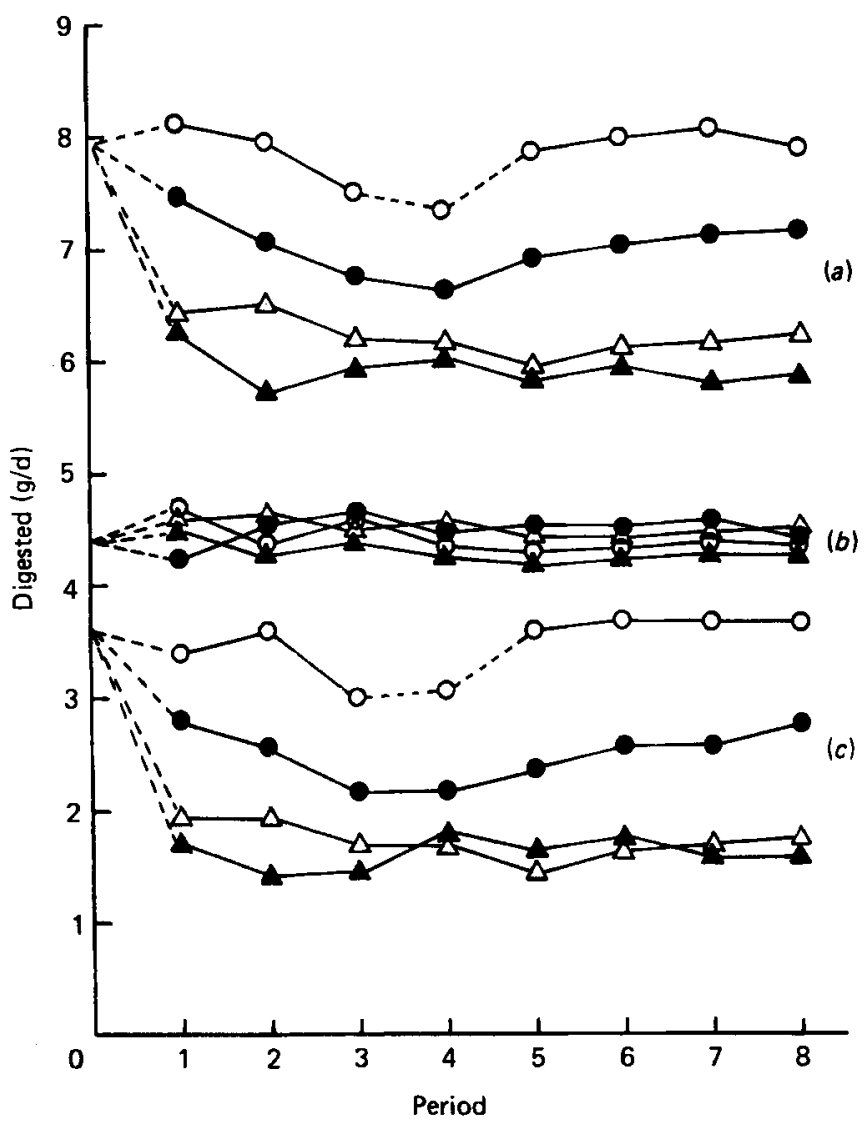

Fig. 1. Effect of monensin on digestion of dry matter (DM) in the Rumen Simulation Technique (Rusitec). The values are expressed as means of results obtained during the following periods: 1 , days 9-12;2, days $13-16 ; 3$, days $17-20 ; 4$, days $21-24 ; 5$, days $25-28 ; 6$, days $29-33 ; 7$, days $34-37 ; 8$, days $38-41$. Monensin was administered from day 7 at the following levels: $(\mathrm{O}-\mathrm{O})$, no monensin; $(\mathrm{O}-\mathrm{O}), 2 \mathrm{mg} / \mathrm{d} ;(\Delta-\Delta)$, $10 \mathrm{mg} / \mathrm{d}$; (A- $\mathbf{\Delta}), 50 \mathrm{mg} / \mathrm{d}$. (a) Total DM digestion, (b) digestion of non-fibrous material, (c) digestion of fibre.

(Fig. 1; Table 1). The ratio, cellulose digested:hemicellulose digested, did not change significantly with the addition of monensin (6:4 in all vessels) but the total fibre digested in $48 \mathrm{~h}$ fell on average by 27,50 and $56 \%$ in vessels nos. 2, 3 and 4 (Table 1).

During days 25-28, the effect of monensin on the initial rate of digestion was investigated by incubating food in small nylon bags similar to the larger nylon bags used routinely. Monensin had no significant effect on the initial digestion of $\mathrm{DM}$, the mean $( \pm \mathrm{SE} ; \%)$ values for the four vessels being $12 \cdot 8 \pm 0 \cdot 8,16 \cdot 1 \pm 1 \cdot 0,23 \cdot 2 \pm 0 \cdot 7$ and $24 \cdot 1 \pm 0 \cdot 4$ after $3,6,9$ and $12 \mathrm{~h}$ incubation respectively. In contrast, digestion was depressed by monensin when the small bags were incubated for 24 and $48 \mathrm{~h}$, as it was in the larger bags. However, the extent of DM digestion was apparently higher at $24 \mathrm{~h}$ than at $48 \mathrm{~h}$ in the small bags, whereas in the larger bags, with the larger pore size, digestion at $24 \mathrm{~h}$ was $0.81 \pm 0.01$ of the digestion at $48 \mathrm{~h}$. The reason for this apparent anomaly was not established.

At the end of the experiment, the large bags which had been incubated for only $24 \mathrm{~h}$ were analysed. Cellulose digested was $1 \cdot 69,1 \cdot 11,0.34$ and $0.49 \mathrm{~g}$, and hemicellulose digested was $0.64,0.63,0.03$ and $0.11 \mathrm{~g}$ in vessels nos. $1-4$ respectively, giving values for fibre digestion of $2 \cdot 33,1 \cdot 74,0.37$ and $0.60 \mathrm{~g}$ respectively. These values compare with average $48 \mathrm{~h}$ values 
Table 1. Digestion $(\mathrm{g} / \mathrm{d})$ of fibrous components and total dry matter (DM) in food after $48 \mathrm{~h}$ incubation in Rusitec

(The input of DM, cellulose and hemicellulose was $13.06,4.56$ and $2.89 \mathrm{~g} / \mathrm{d}$ respectively)

\begin{tabular}{|c|c|c|c|c|c|c|}
\hline Monensin (mg/d)... & Period (d) & 0 & 2 & 10 & 50 & SE \\
\hline DM & $\begin{array}{c}\text { Control* } \\
9-20 \\
29-41\end{array}$ & $\begin{array}{l}8.00 \\
7.83 \\
8 \cdot 00\end{array}$ & $\begin{array}{l}7 \cdot 82 \\
7 \cdot 03 \\
7 \cdot 10\end{array}$ & $\begin{array}{l}7 \cdot 77 \\
6 \cdot 33 \\
6 \cdot 10\end{array}$ & $\begin{array}{l}7 \cdot 75 \\
5 \cdot 90 \\
5 \cdot 94\end{array}$ & $\begin{array}{l}0.21 \\
0.12 \\
0.07\end{array}$ \\
\hline Cellulose & $\begin{array}{c}\text { Cont:ol† } \\
9-20 \\
29-41\end{array}$ & $\begin{array}{l}2 \cdot 20 \\
2 \cdot 02 \\
2 \cdot 20\end{array}$ & $\begin{array}{l}1.48 \\
1.63\end{array}$ & $\begin{array}{l}1.06 \\
0.99\end{array}$ & $\begin{array}{l}0.90 \\
0.94\end{array}$ & $\begin{array}{l}0.14 \\
0.05\end{array}$ \\
\hline Hemicellulose & $\begin{array}{c}\text { Control } \dagger \\
9-20 \\
29-41\end{array}$ & $\begin{array}{l}1 \cdot 40 \\
1 \cdot 35 \\
1 \cdot 45\end{array}$ & $\begin{array}{l}1.03 \\
1.01\end{array}$ & $\begin{array}{l}0.77 \\
0.69\end{array}$ & $\begin{array}{l}0.62 \\
0.64\end{array}$ & $\begin{array}{l}0.07 \\
0.03\end{array}$ \\
\hline Non-fibrous DM & $\begin{array}{c}\text { Controlt } \\
9-20 \\
29-41\end{array}$ & $\begin{array}{l}4 \cdot 51 \\
4 \cdot 46 \\
4 \cdot 35\end{array}$ & $\begin{array}{l}4 \cdot 52 \\
4 \cdot 46\end{array}$ & $\begin{array}{l}4 \cdot 50 \\
4 \cdot 42\end{array}$ & $\begin{array}{l}4 \cdot 38 \\
4 \cdot 36\end{array}$ & $\begin{array}{l}0.08 \\
0.05\end{array}$ \\
\hline
\end{tabular}

* Days 1-5. Monensin was added on day 7

+ Calculated from analyses of pooled residues from vessels nos. 1-4 removed on days 5 and 6 .

Table 2. Summary of outputs ( $\mathrm{mmol} / \mathrm{d})$ of methane and volatile fatty acids $(V F A)$ in Rusitec

\begin{tabular}{|c|c|c|c|c|c|c|}
\hline Monensin (mg/d)... & Period (d) & 0 & 2 & 10 & 50 & SE \\
\hline Methane & $\begin{array}{c}\text { Control* } \\
9-21) \\
29-4 i\end{array}$ & $\begin{array}{l}15 \cdot 1 \\
10 \cdot 8 \\
12 \cdot 1\end{array}$ & $\begin{array}{r}14.6 \\
5.8 \\
7.5\end{array}$ & $\begin{array}{r}13 \cdot 8 \\
3.3 \\
4.8\end{array}$ & $\begin{array}{r}15 \cdot 3 \\
2 \cdot 5 \\
4 \cdot 6\end{array}$ & $\begin{array}{l}2.1 \\
0.4 \\
0.5\end{array}$ \\
\hline Acetate & $\begin{array}{c}\text { Control } \\
9-2(1 \\
29-41\end{array}$ & $\begin{array}{l}33 \cdot 9 \\
32 \cdot 1 \\
31 \cdot 5\end{array}$ & $\begin{array}{l}32 \cdot 6 \\
24 \cdot 7 \\
28 \cdot 1\end{array}$ & $\begin{array}{l}32 \cdot 3 \\
20 \cdot 0 \\
21 \cdot 7\end{array}$ & $\begin{array}{l}34 \cdot 5 \\
18 \cdot 2 \\
21 \cdot 0\end{array}$ & $\begin{array}{l}2.0 \\
0.9 \\
0.6\end{array}$ \\
\hline Propionate & $\begin{array}{c}\text { Control } \\
9-20 \\
29-41\end{array}$ & $\begin{array}{l}12 \cdot 3 \\
17 \cdot 1 \\
14 \cdot 3\end{array}$ & $\begin{array}{l}11 \cdot 7 \\
21 \cdot 1 \\
20 \cdot 4\end{array}$ & $\begin{array}{l}11 \cdot 5 \\
21 \cdot 6 \\
21 \cdot 6\end{array}$ & $\begin{array}{l}12 \cdot 5 \\
21-5 \\
22 \cdot 0\end{array}$ & $\begin{array}{l}0.6 \\
0.8 \\
0.5\end{array}$ \\
\hline Butyrate & $\begin{array}{c}\text { Contral } \\
9-20 \\
29-41\end{array}$ & $\begin{array}{r}13 \cdot 0 \\
9 \cdot 2 \\
10 \cdot 3\end{array}$ & $\begin{array}{r}12 \cdot 8 \\
4.6 \\
5.5\end{array}$ & $\begin{array}{r}12 \cdot 1 \\
2 \cdot 6 \\
3 \cdot 0\end{array}$ & $\begin{array}{r}12 \cdot 0 \\
1 \cdot 8 \\
2 \cdot 3\end{array}$ & $\begin{array}{l}1.4 \\
0.5 \\
0.2\end{array}$ \\
\hline Isovalerate & $\begin{array}{c}\text { Contrcl } \\
9-20 \\
29-41\end{array}$ & $\begin{array}{l}1 \cdot 7 \\
1 \cdot 2 \\
2 \cdot 1\end{array}$ & $\begin{array}{l}1.5 \\
0.2 \\
0.1\end{array}$ & $\begin{array}{l}1 \cdot 2 \\
0 \cdot 3 \\
0\end{array}$ & $\begin{array}{l}1 \cdot 2 \\
0 \cdot 3 \\
0\end{array}$ & $\begin{array}{l}0.1 \\
0.2 \\
0.1\end{array}$ \\
\hline Valerate & $\begin{array}{c}\text { Control } \\
9-20 \\
29-41\end{array}$ & $\begin{array}{l}1 \cdot 4 \\
2 \cdot 3 \\
3 \cdot 4\end{array}$ & $\begin{array}{l}1 \cdot 6 \\
2 \cdot 2 \\
2 \cdot 6\end{array}$ & $\begin{array}{l}1.4 \\
1.9 \\
2.3\end{array}$ & $\begin{array}{l}1 \cdot 1 \\
1 \cdot 4 \\
1 \cdot 7\end{array}$ & $\begin{array}{l}0.7 \\
0.2 \\
0.2\end{array}$ \\
\hline Total VFA & $\begin{array}{c}\text { Control } \\
9-20 \\
29-41\end{array}$ & $\begin{array}{l}62 \cdot 4 \\
62 \cdot 0 \\
61 \cdot 5\end{array}$ & $\begin{array}{l}60 \cdot 2 \\
52 \cdot 9 \\
56 \cdot 6\end{array}$ & $\begin{array}{l}58 \cdot 6 \\
46 \cdot 3 \\
48 \cdot 4\end{array}$ & $\begin{array}{l}61 \cdot 3 \\
43 \cdot 2 \\
46 \cdot 9\end{array}$ & $\begin{array}{l}2 \cdot 7 \\
1 \cdot 2 \\
1 \cdot 2\end{array}$ \\
\hline
\end{tabular}

* Days 1-5. Monensin was added on day 7. 


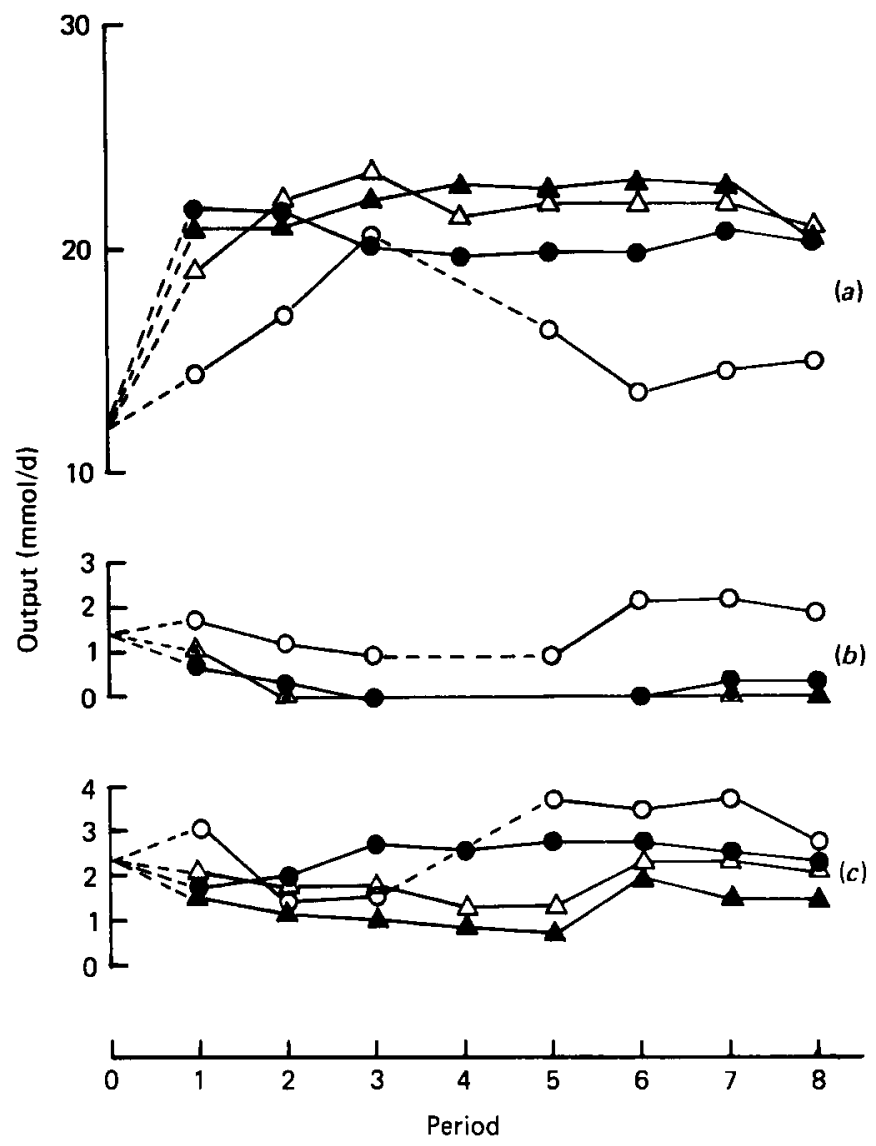

Fig. 2. Effect of monensin on the production of $(a)$ propionate, $(b)$ isovalerate and $(c)$ valerate. The values are expressed as means of results obtained during the following periods: 1 , days $9-12 ; 2$, days 13-16; 3 , days $17-20 ; 4$, days $21-24 ; 5$, days $25-28 ; 6$, days $29-33 ; 7$, days $34-37 ; 8$, days $38-41$. Monensin was administered from day 7 at the following levels: $(\mathrm{O}-\mathrm{O})$, no monensin; $(\mathrm{O}-\mathrm{O}), 2 \mathrm{mg} / \mathrm{d} ;(\triangle-\triangle)$, $10 \mathrm{mg} / \mathrm{d} ;(\Delta-\Delta), 50 \mathrm{mg} / \mathrm{d}$.

during days $29-41$ of $3.65,2.64,1.68$ and $1.58 \mathrm{~g}$ respectively (Table 1 ). Thus, even allowing for considerable error in the measurement of fibre digestion in single samples, it appears that monensin affects mainly the initial rate of fibre digestion, but not its rate subsequently, since approximately the same amount of fibre was digested during the second $24 \mathrm{~h}$ of incubation in all vessels.

\section{Effect of monensin on fermentation products}

Monensin increased propionate production and depressed production of acetate, butyrate, isovalerate, valerate and methane (Table 2). No formate was found in any of the vessels. The effect was in all instances immediate, but as the experiment progressed there was considerable drift both in the untreated vessel and in those receiving monensin. Propionate production in vessels nos. 2-4 increased immediately monensin was added, but also increased more slowly in the control vessel (Fig. 2), until it fell again and remained at its initial level after day 29. The main drift occurring in monensin-treated vessels was in methane production, which after an immediate fall increased progressively as the experiment continued (Fig. 3). This was accompanied by a drift towards increased acetate and butyrate 


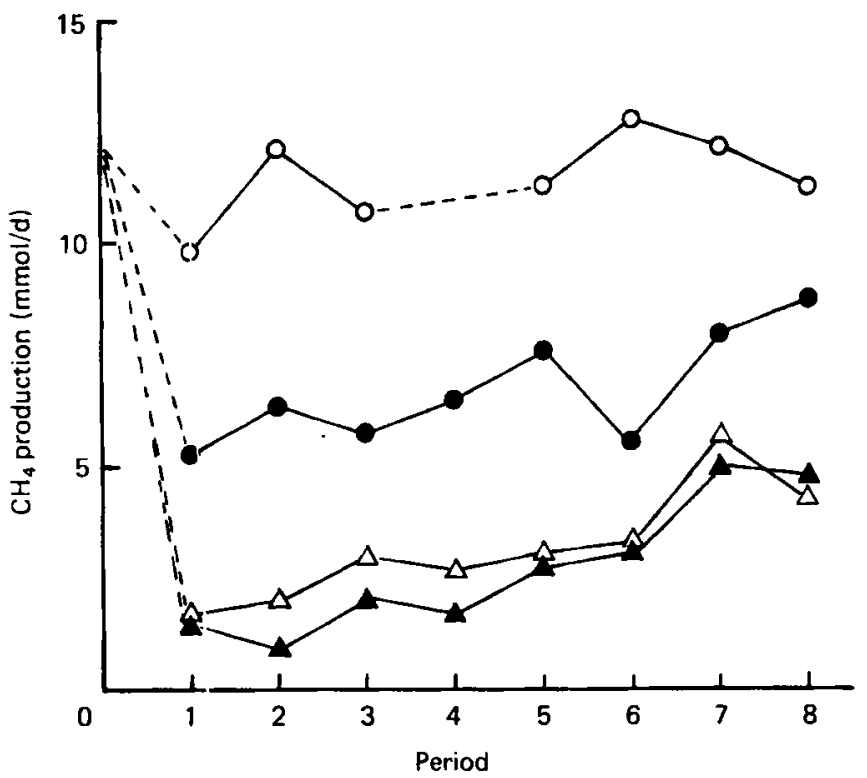

Fig. 3. Effect of monensin on mithane production. The values are expressed as means of results obtained during the following periods: 1 , days $9-12 ; 2$, days $13-16 ; 3$, days $17-20 ; 4$, days $21-24$; 5 , days $25-28$; 6 , days $29-33 ; 7$, days $34-37 ; 8$, days $38-41$. Monensin was administered from day 7 at the following levels: $(\mathrm{O}-\mathrm{O})$, no monensin; $\left(\bigcirc^{-}\right), 2 \mathrm{mg} / \mathrm{d} ;(\triangle-\triangle), 10 \mathrm{mg} / \mathrm{d} ;(\Delta-\Delta), 50 \mathrm{mg} / \mathrm{d}$.

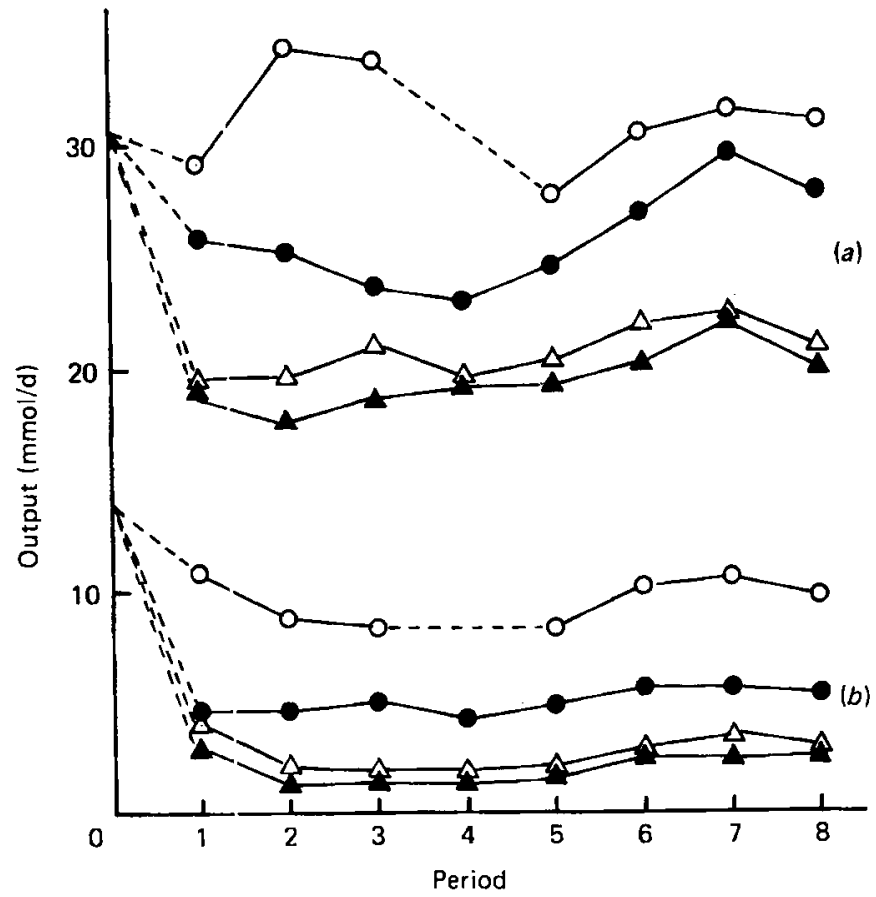

Fig. 4. Effect of monensin on the production of $(a)$ acetate and $(b)$ butyrate. The values are expressed as means of results obtained during the following periods: 1 , days $9-12 ; 2$, days $13-16 ; 3$, days $17-20$; 4, days 21-24; 5 , days $25-28 ; 6$, days $29-33 ; 7$, days 34-37; 8, days 38-41. Monensin was administered from day 7 at the following levels: $(O-O)$, no monensin; $(O-O), 2 \mathrm{mg} / \mathrm{d} ;(\triangle-\triangle), 10 \mathrm{mg} / \mathrm{d} ;(\Delta-\Delta)$, $50 \mathrm{mg} / \mathrm{d}$. 
Table 3. Output of methane and volatile fatty acids (VFA) expressed per unit of food digested

\begin{tabular}{|c|c|c|c|c|c|c|}
\hline Monensin (mg/d)... & Period (d) & 0 & 2 & 10 & 50 & SE \\
\hline Methane (mmol/g) & $\begin{array}{c}\text { Control }^{*} \\
9-20 \\
29-41\end{array}$ & $\begin{array}{l}1.90 \\
1.35 \\
1.52\end{array}$ & $\begin{array}{l}1.88 \\
0.83 \\
1.38\end{array}$ & $\begin{array}{l}1.79 \\
0.53 \\
0.77\end{array}$ & $\begin{array}{l}1 \cdot 97 \\
0.42 \\
0.77\end{array}$ & $\begin{array}{l}0.30 \\
0 \cdot 06 \\
0.07\end{array}$ \\
\hline VFA (mmol/g) & $\begin{array}{c}\text { Control } \\
9-20 \\
29-41\end{array}$ & $\begin{array}{l}7.80 \\
7.77 \\
7.69\end{array}$ & $\begin{array}{l}7.71 \\
7.53 \\
7.95\end{array}$ & $\begin{array}{l}7.53 \\
7.29 \\
8.00\end{array}$ & $\begin{array}{l}7.90 \\
7.20 \\
8.00\end{array}$ & $\begin{array}{l}0 \cdot 31 \\
0 \cdot 18 \\
0 \cdot 18\end{array}$ \\
\hline Energy retained in VFA $(\mathrm{kJ} / \mathrm{g})$ & $\begin{array}{c}\text { Control } \\
9-20 \\
29-41\end{array}$ & $\begin{array}{l}10.95 \\
10.69 \\
11.05\end{array}$ & $\begin{array}{l}10 \cdot 68 \\
10 \cdot 15 \\
10 \cdot 62\end{array}$ & $\begin{array}{r}10.29 \\
9.84 \\
10.60\end{array}$ & $\begin{array}{r}10.61 \\
9.66 \\
10.59\end{array}$ & $\begin{array}{l}0.48 \\
0.21 \\
0.27\end{array}$ \\
\hline $\begin{array}{l}\text { Substrate used for VFA production } \dagger \\
(\mathrm{mmol} \text { hexose/g) }\end{array}$ & $\begin{array}{c}\text { Control } \\
9-20 \\
29-41\end{array}$ & $\begin{array}{l}4.97 \\
4.72 \\
4.83\end{array}$ & $\begin{array}{l}4 \cdot 87 \\
4 \cdot 27 \\
4 \cdot 55\end{array}$ & $\begin{array}{l}4 \cdot 71 \\
4 \cdot 02 \\
4 \cdot 38\end{array}$ & $\begin{array}{l}4.88 \\
3.91 \\
4.35\end{array}$ & $\begin{array}{l}0.20 \\
0 \cdot 09 \\
0 \cdot 11\end{array}$ \\
\hline $\begin{array}{l}\text { Efficiency of energy retention } \\
(\mathbf{k J} / \mathrm{mmol} \text { hexose used) }\end{array}$ & $\begin{array}{c}\text { Control } \\
9-20 \\
29-41\end{array}$ & $\begin{array}{l}2 \cdot 20 \\
2 \cdot 27 \\
2 \cdot 29\end{array}$ & $\begin{array}{l}2 \cdot 19 \\
2 \cdot 38 \\
2 \cdot 33\end{array}$ & $\begin{array}{l}2 \cdot 18 \\
2 \cdot 45 \\
2 \cdot 42\end{array}$ & $\begin{array}{l}2 \cdot 18 \\
2 \cdot 47 \\
2 \cdot 43\end{array}$ & $\begin{array}{l}0.02 \\
0.01 \\
0.01\end{array}$ \\
\hline
\end{tabular}

* Days 1-5. Monensin was added on day 7.

+ From VFA production data (Table 2 ), 0.5 (acetate + propionate) + butyrate + C5 acids $=$ hexose used.

production (Fig. 4). The accidental addition of monensin to vessel no. 1 on day 20 caused an immediate drop in methane production, and values for methane and VFA for the period immediately following have been omitted from Fig. 2.

The lowest level of monensin produced all the previously-mentioned effects, only to a lesser extent. There was generally little difference between the effects of the two higher doses. Dosage level had no significant effect on drift.

When fermentation products were expressed in terms of DM digested, it became clear that monensin decreased the output of methane even when allowance was made for the decreased DM digestibility (Table 3). There was, however, little effect on total VFA production, except that the altered products decreased the efficiency of retention of energy in VFA in the presence of monensin (Table 3). This is the opposite effect to that normally expected with monensin (e.g. Richardson et al. 1976) and occurred partly because the increased production of propionate was counterbalanced energetically by decreased $\mathrm{C} 4$ and $\mathrm{C} 5$ acids (Table 2), but mainly because less of the DM which was lost from the solid food was actually fermented to VFA (Table 3). The quantity of carbohydrate which had to be fermented to account for the observed VFA can be calculated from the concentrations of the products in a way similar to that described by Van Nevel \& Demeyer (1977). When this was compared with the loss of DM actually measured, it was found that less of the digested DM was devoted to VFA production in the presence of monensin, suggesting either that more of the DM was escaping from the food bag without total degradation or that more was incorporated into microbial biomass.

\section{Effect of monensin on the synthesis of microbial matter}

Numbers and types of microbes. Total numbers of protozoa in compartment no. 1 (free liquid suspension) declined with monensin, and a similar trend was observed in compartment no. 2 (space occupied by micro-organisms which can be washed from the solid digesta) (Table 4). Polyplastron was present in the donor sheep and initially in Rusitec, but following 
Table 4. Effect of monerisin on microbial numbers in the Rumen Simulation Technique (Rusitec)

(The results are means of cluplicate determinations on single days in compartment no. $2^{*}$ or means of determinations on three to four different days in compartment no. $1^{*}$. The values in parentheses refer to the percentage of holotrich protozoa)

\begin{tabular}{|c|c|c|c|c|c|}
\hline Monensin $(\mathrm{mg} / \mathrm{d}) \ldots$ & & 0 & 2 & 10 & 50 \\
\hline \multicolumn{6}{|l|}{ Compartment no. 1} \\
\hline Protozoa $\left(10^{-4} \times\right.$ no. $\left./ \mathrm{ml}\right)$ & $\begin{array}{r}\text { Days } 9-22 \\
27-40\end{array}$ & $\begin{array}{l}3 \cdot 2(7) \\
2 \cdot 3(17)\end{array}$ & $\begin{array}{l}2 \cdot 1(10) \\
2 \cdot 1(5)\end{array}$ & $\begin{array}{l}0.5(17) \\
0.8(1)\end{array}$ & $\begin{array}{l}0.015(14) \\
0.4(0)\end{array}$ \\
\hline Bacteria $\left(10^{-10} \times\right.$ no. $\left./ \mathrm{ml}\right)$ & $\begin{array}{r}\text { Days } 9-22 \\
27-40\end{array}$ & $\begin{array}{l}3 \cdot 9 \\
6 \cdot 2\end{array}$ & $\begin{array}{l}5 \cdot 2 \\
9 \cdot 0\end{array}$ & $\begin{array}{l}4 \cdot 4 \\
5 \cdot 3\end{array}$ & $\begin{array}{l}6 \cdot 3 \\
9 \cdot 4\end{array}$ \\
\hline \multicolumn{6}{|l|}{ Compartment no. $2^{*}$} \\
\hline Protozoa $\left(10^{-4} \times\right.$ no. $\left./ \mathrm{ml}\right)$ & $\begin{array}{r}\text { Days } 9-22 \\
27-40\end{array}$ & $\begin{array}{r}39 \cdot 2(7) \\
5.9(0)\end{array}$ & $\begin{array}{c}33 \cdot 6(41) \\
8 \cdot 7(0)\end{array}$ & $\begin{array}{c}11.5(24) \\
7.0(0)\end{array}$ & $\begin{array}{c}12.0(12) \\
5 \cdot 2(0)\end{array}$ \\
\hline Bacteria $\left(10^{-10} \times \mathrm{no} . / \mathrm{ml}\right)$ & $\begin{array}{r}\text { Days } 9-22 \\
27-40\end{array}$ & $\begin{array}{l}18 \cdot 2 \\
29 \cdot 7\end{array}$ & $\begin{array}{l}16 \cdot 6 \\
27 \cdot 0\end{array}$ & $\begin{array}{l}14 \cdot 8 \\
50 \cdot 5\end{array}$ & $\begin{array}{l}14 \cdot 8 \\
42 \cdot 0\end{array}$ \\
\hline
\end{tabular}

* Compartment no. 1 is the free suspension of micro-organisms; compartment no. 2 is the material that can be removed from solid digesta by washing with artificial saliva.

Table 5. Effect of monensin on the output of microbial dry matter $(D M ; g / d)$ in Rusitec

(The results are means for tulked samples for periods 1,2 and 3 (days 9-20) and periods 6.7 and 8 (days 29-41))

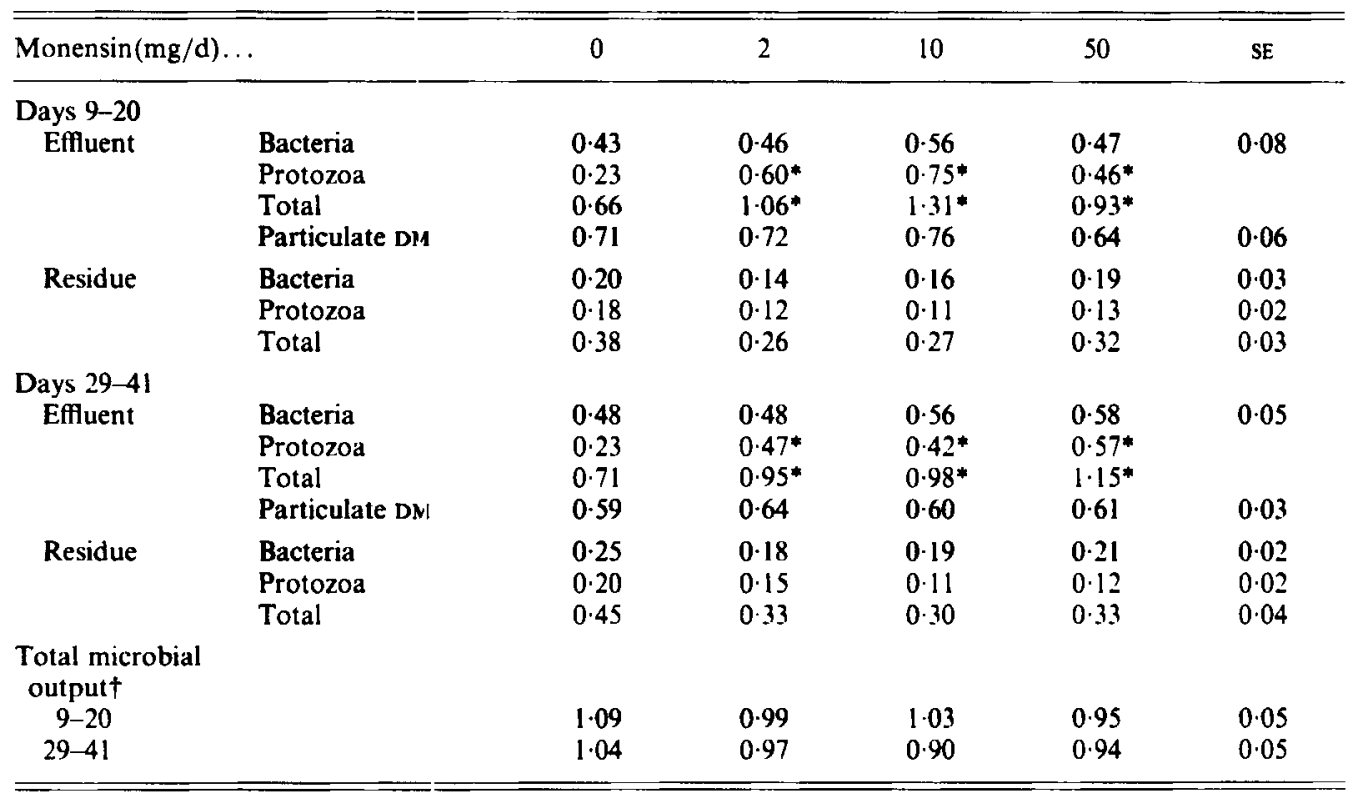

- Values considered to be incorrect because of possible effects of monensin on the relationship between aminoethyl phosphonic acid (AEP) and protozoal biomass.

+ The sum of the particulate DM in the effluent and microbial matter in the residue. 
Table 6. Distribution and recovery of protein and total nitrogen in Rusitec during administration of monensin

(Values are means. The mean input of $N(\mathrm{mg} / \mathrm{d})$ was 176.3 in food, 23.3 in solid urea and $77.3 \pm 0.6$ in infusion buffer, i.e. total $277 \mathrm{mg} / \mathrm{d}$. The input of protein measured by $\alpha$-amino groups $(\mathrm{mmol} \times 102)$ was $436.9 \mathrm{mg} / \mathrm{d}$ with food)

\begin{tabular}{|c|c|c|c|c|c|}
\hline Monensin $(\mathrm{mg} / \mathrm{d}) \ldots$ & 0 & 2 & 10 & 50 & SE \\
\hline \multicolumn{6}{|l|}{ Nitrogen (mg/d) } \\
\hline $\begin{array}{l}\text { Effluent } \\
\text { Residue } \\
\text { Recovery (\%) }\end{array}$ & $\begin{array}{r}217 \\
58 \\
100\end{array}$ & $\begin{array}{r}209 \\
59 \\
97\end{array}$ & $\begin{array}{r}210 \\
67 \\
100\end{array}$ & $\begin{array}{r}199 \\
83 \\
101\end{array}$ & $\begin{array}{l}7 \\
6\end{array}$ \\
\hline $\begin{array}{l}\text { Days } 29-41 \\
\quad \text { Effluent } \\
\text { Residue } \\
\text { Recovery }(\%)\end{array}$ & $\begin{array}{r}199 \\
71 \\
98\end{array}$ & $\begin{array}{r}204 \\
72 \\
100\end{array}$ & $\begin{array}{r}200 \\
77 \\
101\end{array}$ & $\begin{array}{r}202 \\
95 \\
103\end{array}$ & $\begin{array}{l}3 \\
4\end{array}$ \\
\hline $\begin{array}{l}\text { Protein }(\mathrm{mg} / \mathrm{d}) \\
\text { Days } 9-20\end{array}$ & & & & & \\
\hline $\begin{array}{l}\text { Effluent } \\
\text { Residue* } \\
\text { Output - input }\end{array}$ & $\begin{array}{r}202 \\
165 \\
-70\end{array}$ & $\begin{array}{r}237 \\
167 \\
-30\end{array}$ & $\begin{array}{r}266 \\
230 \\
+62\end{array}$ & $\begin{array}{r}225 \\
255 \\
+46\end{array}$ & $\begin{array}{l}12 \\
24\end{array}$ \\
\hline $\begin{array}{l}\text { Days 29-4l } \\
\text { Effluent } \\
\text { Residue* } \\
\text { Output -input }\end{array}$ & $\begin{array}{r}183 \\
250 \\
-40\end{array}$ & $\begin{array}{r}216 \\
243 \\
+25\end{array}$ & $\begin{array}{r}212 \\
275 \\
+53\end{array}$ & $\begin{array}{r}219 \\
326 \\
+111\end{array}$ & $\begin{array}{l}12 \\
24\end{array}$ \\
\hline
\end{tabular}

- Corrected for low extraction of nitrogenous compounds.

the addition of urea appeared only occasionally and in small numbers $(<1 \%$ of total) in compartment no. 1 of vessel no. 1 . At the end of the experiment, Polyplastron constituted approximately $20 \%$ of protozoal numbers in compartment no. 2 of vessel no. 1 , but was absent from vessels receiving monensin. Monensin had no discernible effect on bacterial numbers (Table 4), although it was noted that the drug affected the composition of the flora. Relative numbers of Gram-positive cocci decreased and Gram-negative curved rods increased with monensin. Gram-positive tetracocci were eliminated by monensin.

Production of microbial biomass. Earlier work with Rusitec (e.g. Czerkawski \& Breckenridge, 1977) indicated that particulate DM in the effluent could be equated with microbial matter as calculated from the diaminopimelic acid (DAP) and aminoethylphosphonic acid (AEP) content of the effluent. While the results from vessel no. 1 were consistent with this relationship, it was found that the AEP content of the effluent from monensin-treated vessels was abnormally high, and that as a consequence the microbial matter estimated from DAP and AEP considerably exceeded the particulate DM produced (Table 5). As this is clearly not possible, it was concluded that monensin affected the value for AEP:biomass in protozoa in free suspension so that the usual conversion factor was not valid. For the purposes of this experiment it was therefore assumed that microbial matter in the effluent was equivalent to the total particulate DM.

The output of DAP in the undigested residue in this experiment was lower than in most previous experiments and also introduced some difficulties not previously encountered. The efficiency of extraction of $\mathbf{N}$ from the solid phase, by sonication and extraction with dilute $\mathrm{NaOH}$, was $85,81,70$ and $66 \%$ of total $\mathrm{N}$ in vessels nos. $1,2,3$ and 4 , compared with $>95 \%$ normally achieved. When $\alpha$-amino group and DAP production were adjusted to $100 \% \mathrm{~N}$ recovery, their content as a proportion of DM in the undigested residue from all vessels became equal. 
Table 7. Efficiency of microbial growth and hydrogen recovery

\begin{tabular}{|c|c|c|c|c|c|}
\hline Monensin $(\mathrm{mg} / \mathrm{d}) \ldots$ & 0 & 2 & 10 & 50 & SE \\
\hline \multicolumn{6}{|c|}{ Efficiency } \\
\hline $\begin{array}{l}\text { Days } 9-20 \\
\text { Days } 29-41\end{array}$ & $\begin{array}{l}0.138 \\
0.130\end{array}$ & $\begin{array}{l}0 \cdot 139 \\
0.136\end{array}$ & $\begin{array}{l}0.163 \\
0.145\end{array}$ & $\begin{array}{l}0.159 \\
0 \cdot 161\end{array}$ & $\begin{array}{l}0.007 \\
0.007\end{array}$ \\
\hline \multicolumn{6}{|c|}{ ATP yield* (mmol/g DM digestied) } \\
\hline $\begin{array}{l}\text { Days } 9-20 \\
\text { Days } 29-41\end{array}$ & $\begin{array}{l}19 \cdot 6 \\
19 \cdot 4\end{array}$ & $\begin{array}{l}19 \cdot 2 \\
20 \cdot 3\end{array}$ & $\begin{array}{l}18 \cdot 7 \\
20 \cdot 3\end{array}$ & $\begin{array}{l}18 \cdot 8 \\
20 \cdot 8\end{array}$ & $\begin{array}{l}0.8 \\
0.5\end{array}$ \\
\hline \multicolumn{6}{|c|}{$\begin{array}{l}\text { Microbial yield per ATP formed }\left(\mathrm{Y}_{\mathrm{ATP}}\right) \\
(\mathrm{g} / \mathrm{mol})\end{array}$} \\
\hline $\begin{array}{l}\text { Days } 9-20 \\
\text { Days } 29-41\end{array}$ & $\begin{array}{l}7 \cdot 1 \\
6 \cdot 7\end{array}$ & $\begin{array}{l}7 \cdot 3 \\
6 \cdot 7\end{array}$ & $\begin{array}{l}8 \cdot 6 \\
7 \cdot 1\end{array}$ & $\begin{array}{l}8.5 \\
7.8\end{array}$ & $\begin{array}{l}0.4 \\
0.3\end{array}$ \\
\hline \multicolumn{6}{|c|}{$\begin{array}{l}\text { Hydrogen balance }(\mathrm{mmol} / \mathrm{d}) \\
\text { Days } 9-20\end{array}$} \\
\hline $\begin{array}{l}\text { Produced } \\
\text { Used }\end{array}$ & 126.7 & $96 \cdot 7$ & $78 \cdot 5$ & $70 \cdot 1$ & $4 \cdot 2$ \\
\hline Methane & $43 \cdot 6$ & $23 \cdot 2$ & $13 \cdot 3$ & $10 \cdot 1$ & $2 \cdot 6$ \\
\hline VFA & 66.4 & $61 \cdot 7$ & $57 \cdot 1$ & $53 \cdot 3$ & $2 \cdot 2$ \\
\hline Cells & 8.9 & 8.0 & 8.4 & $7 \cdot 7$ & 0.4 \\
\hline Total & 118.9 & $92 \cdot 9$ & $78 \cdot 8$ & $71 \cdot 1$ & $2 \cdot 1$ \\
\hline $\begin{array}{l}\text { Days 29-41 } \\
\text { Produced } \\
\text { Used }\end{array}$ & 134.7 & $106 \cdot 6$ & $83 \cdot 7$ & $77 \cdot 9$ & $2 \cdot 7$ \\
\hline Methane & $48 \cdot 4$ & $32 \cdot 5$ & $19 \cdot 1$ & $18 \cdot 3$ & $2 \cdot 5$ \\
\hline VFA & $71 \cdot 1$ & 62.5 & 58.0 & $55 \cdot 0$ & $2 \cdot 2$ \\
\hline Cells & 8.4 & $7 \cdot 8$ & $7-2$ & $7 \cdot 6$ & 0.4 \\
\hline Total & 127.9 & $102 \cdot 8$ & $84 \cdot 3$ & 80.9 & $3 \cdot 3$ \\
\hline
\end{tabular}

VFA, volatile fatty acids; $D M, d r y$ matter.

- ATP yield $(\mathrm{mmol} / \mathrm{d})=2 \mathrm{~A}+3 \mathrm{~F}^{\prime}+2 \mathrm{~B}+3 \mathrm{~V}+\mathrm{CH}_{4}$, where $\mathrm{A}, \mathrm{P}, \mathrm{B}$ and $\mathrm{V}$ are the outputs of acetate, propionate, butyrate and $\mathrm{C} 5$ acids respectively $(\mathrm{mmol} / \mathrm{d})$ (Czerkawski, 1978).

+ Hydrogen produced $=2 \mathrm{~A}+\mathrm{P}+4 \mathrm{~B}+3 \mathrm{~V} \mathrm{mmol} / \mathrm{d}$. Hydrogen used $=2 \mathrm{P}+2 \mathrm{~B}+4 \mathrm{~V}+4 \mathrm{CH}_{4}+(8 \cdot 1 \times$ cell $\mathrm{DM}(\mathrm{g})$ (mmol/d)) (Czerkawski, 1978).

In order to estimate biomass production, therefore, it was assumed that (1) particulate DM = microbial DM in the effluent, and (2) the DAP content of nitrogenous material released from undigested residue was the same as the DAP content of the total $\mathrm{N}$ in the residue. The results calculated in this way indicated that total microbial output tended to decrease slightly with monensin (Table 5). The decreased yield was apparent within two days and there was no drift throughout the experimental period.

$\mathrm{N}$ recovery was good throughout, and the distribution of $\mathrm{N}$ between the effluent and the undigested residue was similar in all four vessels (Table 6). Protein output increased with monensin was added (Table 5), DM digestibility fell even more (Table 1), so that monensin at high monensin, protein output exceeded input, reflecting the utilization of urea-N by the microbial pool.

Efficiency of microbial grcwth. Although the output of microbial DM tended to fall when monensin was added (Table 5), DM digestiblity fell even more (Table 1), so that monensin tended to increase the efficiency of microbial growth in terms of DM produced per unit DM digested (Table 7). As microbial ATP production was changed little by monensin, the yield per mol ATP produced $\left(\mathrm{Y}_{\mathrm{ATP}}\right)$ also tended to increase as the dose increased (Table 7). Metabolic hydrogen diverted from methane production by monensin was recovered in cell material and other products (Table 7), and no $\mathrm{H}_{2}$ was found in the fermentation gas. 
Table 8. Effect of urea and monensin on the concentration of ammonia and urease (EC

$$
\text { 3.5.1.5) activity }
$$

(Samples were removed from compartment no. 1 of Rusitec $2 \mathrm{~h}$ after feeding. Urea was added from day

7 onwards. The results are means of duplicate determinations on single days or means of 3-4 determinations on separate days. The concentration of $\mathrm{NH}_{3}-\mathrm{N}$ in the rumen contents used as inoculum was $17.6 \mu \mathrm{mol} / \mathrm{ml}$ and the urease activity was $9.5 \mu \mathrm{mol} \mathrm{NH}{ }_{3}$ released $/ \mathrm{ml} \mathrm{per} \mathrm{min}$ ).

\begin{tabular}{|c|c|c|c|c|c|}
\hline Monensin $(\mathrm{mg} / \mathrm{d}) \ldots$ & 0 & 2 & 10 & 50 & SE \\
\hline \multicolumn{6}{|l|}{$\begin{array}{l}\mathrm{NH}_{3} \text { concentration } \\
(\mu \mathrm{mol} / \mathrm{ml})\end{array}$} \\
\hline Days 1,2 & $12 \cdot 9$ & $13 \cdot 1$ & $13 \cdot 1$ & $13 \cdot 5$ & \\
\hline Days 5, 6 & $6 \cdot 0$ & 6.2 & $5 \cdot 6$ & 6.6 & \\
\hline Days 8-20 & $15 \cdot 7$ & 14.0 & $12 \cdot 6$ & $12 \cdot 9$ & 0.6 \\
\hline Days $23-41$ & 12.9 & $13 \cdot 4$ & $13 \cdot 4$ & $12 \cdot 3$ & 0.3 \\
\hline \multicolumn{6}{|c|}{$\begin{array}{l}\text { Urease activity } \\
\left(\mu \mathrm{mol} \mathrm{NH}_{3} \text { released } / \mathrm{ml} \text { per min }\right)\end{array}$} \\
\hline Day 1 & 0.52 & 0.53 & 0.52 & 0.48 & \\
\hline Day 2 & 0.14 & $0 \cdot 14$ & $0 \cdot 15$ & 0.15 & \\
\hline Days 3-6 & 0.08 & 0.08 & 0.08 & 0.08 & 0.01 \\
\hline Days 8-20 & 0.70 & 0.76 & 0.85 & 0.78 & 0.09 \\
\hline Days 23-41 & 0.72 & 0.84 & 0.84 & 0.87 & 0.08 \\
\hline
\end{tabular}

Table 9. Influence of monensin on the activity of some enzymes in Rusitec

\begin{tabular}{|c|c|c|c|c|c|c|c|}
\hline $\begin{array}{l}\text { Monensin } \\
(\mathrm{mg} / \mathrm{d})\end{array}$ & $\begin{array}{c}\text { Com- } \\
\text { partment } \\
\text { no. }\end{array}$ & $\begin{array}{c}\text { Protease* } \\
\text { ( } \mu \mathrm{g} \text { azo- } \\
\text { casein } / \mathrm{mg} \\
\text { protein } \\
\text { per h }\end{array}$ & $\begin{array}{c}\text { Alkaline } \\
\text { phos- } \\
\text { phatase } \ddagger \\
(E C \text { 3.1.3.1) }\end{array}$ & $\begin{array}{c}\begin{array}{c}\text { Succinate } \\
\text { dehydro- } \\
\text { genase }\end{array} \\
(E C \text { 1.3.99.1)\& } \\
\text { (nmol INT } \\
\text { reduced/mg } \\
\text { protein } \\
\text { per min) }\end{array}$ & $\begin{array}{c}\text { Acetate } \\
\text { kinase } \\
(E C 2.7 .2 .1) \$ \\
\text { (nmol acetyl } \\
\text { phosphate } \\
\text { formed } / \mathrm{mg} \\
\text { protein } \\
\text { per min) }\end{array}$ & $\begin{array}{c}\text { NADP- } \\
\text { glutamate } \\
\text { dehydro- } \\
\text { genase } \\
(E C 1.4 .1 .4) \dagger \\
(\mu \mathrm{mol} \\
\text { NADPH } \\
\text { oxidized/mg } \\
\text { protein } \\
\text { per min) }\end{array}$ & 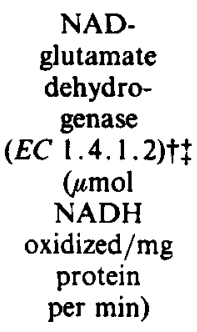 \\
\hline 0 & 1 & $20 \cdot 4$ & 100 & 0.021 & $23 \cdot 3$ & 0.075 & 100 \\
\hline 2 & 1 & $25 \cdot 5$ & 172 & $0 \cdot 110$ & 24.7 & 0.067 & 129 \\
\hline 10 & 1 & $28 \cdot 5$ & 231 & 0.179 & 29.8 & 0.056 & 142 \\
\hline \multirow[t]{2}{*}{50} & 1 & $45 \cdot 8$ & 262 & 0.345 & $30 \cdot 2$ & 0.078 & 246 \\
\hline & $\mathrm{SE}$ & 2.6 & 33 & 0.034 & 2.4 & 0.015 & 36 \\
\hline c & 2 & 6.0 & 100 & 0.052 & 69.7 & 0.038 & 100 \\
\hline 2 & 2 & 6.5 & 141 & 0.267 & 26.7 & 0.027 & 78 \\
\hline 10 & 2 & 7.8 & 181 & 0.411 & $40 \cdot 2$ & 0.038 & 58 \\
\hline \multirow[t]{2}{*}{50} & 2 & 5.5 & 235 & 0.609 & $27 \cdot 5$ & 0.042 & 76 \\
\hline & SE & $1 \cdot 3$ & 37 & 0.126 & 9.5 & 0.007 & 16 \\
\hline
\end{tabular}

* Day 42, six separate determinations.

$\dagger$ Mean of two determinations for samples taken on day 35 and four determinations for samples taken on day 42.

$\$$ Arbitrary units of specific activity, taking activity with zero monensin to be 100 for each compartment. Activity of these enzymes was lost on storage, so only sets of samples treated and stored in an identical way were compared. The highest activities at zero monensin were: for alkaline phosphatase, 7.9 and $3.2 \mathrm{nmol} p$-nitrophenol released/mg protein per min in compartments nos. 1 and 2 measured after storage at $-60^{\circ}$ for $29 \mathrm{~d}$; for NAD-linked glutamate dehydrogenase, 0.38 and $1.09 \mu \mathrm{mol} \mathrm{NADH}$ oxidized $/ \mathrm{mg}$ protein per min in compartments nos. 1 and 2 after $28 \mathrm{~d}$ storage at $-60^{\circ}$.

$\$$ Day 42 , four determinations. 


\section{Effect of monensin on some microbial enzyme activities}

Urease. As was found previously (Cheng $e t$ al. 1979), urease activity fell rapidly following inoculation of Rusitec (Tatle 8). During this time, $\mathrm{NH}_{3}$ concentration was halved (Table 8). Urease activity was restored to levels even higher than those found initially when urea was added from day 7 onwards, and monensin had no effect on urease activity (Table 8). Hydrolysis of this urea resulted in increased $\mathrm{NH}_{3}$ concentrations (Table 8).

Protease. At the end of the experiment, proteolytic activity was estimated in the free suspension (compartment no. 1) and in the washings (compartment no. 2) from the bags incubated for 24 and $48 \mathrm{~h}$ (Table 9). Monensin caused a pronounced increase in the specific activity of compartment no 1, but hardly affected compartment no. 2 , which was of much lower specific activity than compartment no. 1 .

Other enzymes. The activities of several enzymes measured in cell-free sonicated extracts were affected by monensin in different ways (Table 9). Alkaline phosphatase and succinate dehydrogenase activities were increased markedly in all samples, whereas acetate kinase and NAD-linked glutamate dehydrogenase increased in compartment no. 1 but declined in compartment no. 2 when monensin was present. Glutamate dehydrogenase activity coupled to the oxidation of NADPH was unaffected by monensin. The relative specific activities of the enzymes in the two ccmpartments similarly varied from enzyme to enzyme. Alkaline phosphatase and, to a lesser extent, NADP-linked glutamate dehydrogenase were higher in compartment no. 1 than in compartment no. 2. On the other hand, the opposite held for succinate dehydrogenase and NAD-linked glutamate dehydrogenase. Acetate kinase activity, which in the absenie of monensin was higher in compartment no. 2, was similar in both compartments of vessels receiving monensin.

\section{DISCUSSION}

The use of Rusitec in this experiment eliminated problems associated with host-rumen interactions and at the same time enabled calculation of the long-term effects of monensin on rumen energy transformations in greater detail than has previously been possible. The two main effects were that monensin decreased the digestibility of DM apparently by delaying fibre digestion (Table 1), and that it altered the stoichiometry of the fermentation to one of higher propionate and lower methane production (Table 2). The latter effect has been seen in practically all studies of the effect of monensin on fermentation products but the effect of monensin on food digestion is not one which is commonly observed.

It should be noted here that, although the doses used in this experiment appear to be high $(153 \mu \mathrm{g} / \mathrm{g}$ food at the lowest level), the dispersal of monensin into the liquid phase of Rusitec diluted the additive more than would occur in the rumen. The concentrations of monensin which would be expected in the liquid phase of vessels nos. 2, 3 and 4 can be calculated to be $2 \cdot 7,13.7$ and $66 \cdot 1 \mu \mathrm{g} / \mathrm{ml}$. In comparison, the probable concentration of monensin in the sheep rumen at an optimum monensin level of approximately $10 \mu \mathrm{g} / \mathrm{g}$ food (Nockels et al. 1978; Joyner et al. 1979) would be approximately $2.5 \mu \mathrm{g} / \mathrm{ml}$ for an animal of rumen volume $4 \mathrm{l}$, turning over at $1.2 / \mathrm{d}$, receiving $1.2 \mathrm{~kg}$ food/d. Vessel no. 2 may therefore be considered to contain monensin at close to the optimal practical dose, while the monensin concentrations in vessels nos. 3 and 4 would be counterproductive in vivo.

In feeding trials, monensin is usually found to have little effect on (Dinius et al. 1976; Utley et al. 1977) or even to increase (Allen \& Harrison, 1979; Horton \& Stockdale, 1979; Joyner et al. 1979) digestibility, in contrast to the significant decreases in DM digestibility found in the present study (Table 1), in some other incubations in vitro (Lemenager $e t$ al. 1978; Slyter, 1979) and occzssionally in vivo (Poos et al. 1979). The most likely explanation 
for these differences is that while the liquid turnover time and period of incubation of food was held constant in Rusitec (approximately $0.038 / \mathrm{h}$ and $48 \mathrm{~h}$ respectively), monensin lengthens retention time in vivo (Lemenager et al. 1978; Allen \& Harrison, 1979), so that any change in rate of degradation may be compensated in vivo by changes in the dilution rate, such that the same or an even higher degradability is obtained.

The efficacy of monensin in improving food efficiency in ruminants is often attributed partly to an improved energetic efficiency of the rumen fermentation (e.g. Richardson et al. 1976). As less energy is dissipated in methane production, more should be retained in VFA. This did not apply in Rusitec when expressed in units of DM digested (Table 3), mainly because the hexose required to produce the observed fermentation products was a smaller proportion of the DM digested in the presence of monensin (Table 3 ). When expressed in terms of hexose actually used for the production of VFA and methane the efficiency of energy conservation increased as predicted (Table 3).

The microbial yield was apparently increased at the higher concentrations of monensin (Table 7), in contrast to the findings of Van Nevel \& Demeyer $(1977,1979)$ and Allen \& Harrison (1979) but similar to our earlier findings in a short-term experiment (Wallace et al. 1980). Although the reasons for these differences remain unknown, it is possible that the different methods used in the estimation of microbial growth may be responsible. In our experiments we have assumed that the diaminopimelic acid (DAP) content of bacteria associated with the residue is the same in the presence and absence of monensin, despite changes in the over-all bacterial population. We have no means of knowing if this is a valid assumption. Similarly, the aminoethyl phosphonic acid (AEP) content of the effluent increased (Table 5) despite the marked reduction in protozoal numbers (Table 4). We suspect that this is due to breakdown of protozoa, so that the fragments of protozoal walls are measured by the chemical but not the microscopic method, but again we have no proof of this. Factors in favour of our results, on the other hand, are that most of the microbial matter production was based on the particulate DM content of the effluent, which in the past has been found to be equivalent to microbial DM (Czerkawski \& Breckenridge, 1977; $1979 a, b)$ and represents most of the microbial matter produced (Table 5) and that changes in the DAP and AEP content of bacteria and protozoa associated with the residue would probably have relatively minor effects on the estimation of total microbial matter. The increase in microbial yield might well be a consequence of the decrease in the numbers of protozoa (Table 4), whether caused by decreased turnover due to predation (Jarvis, 1968) or by a more direct effect on yield (Demeyer \& Van Nevel, 1979). In any event, one of the main effects of monensin appears to be to divert $\mathrm{C}$ away from VFA production, as discussed previously, towards greater microbial growth.

Another reported aspect of the feeding of monensin is that it increases the retention of dietary N (Dinius et al. 1976; Dartt et al. 1978; Joyner et al. 1979). The increased propionate production with monensin is likely to be largely responsible for this effect, by sparing glucogenic amino acids from gluconeogenesis (Leng et al. 1967), but there may additionally be direct effects on the $\mathbf{N}$ metabolism of the rumen microbial population. Monensin inhibited the digestion of casein in short incubations in vitro (Van Nevel \& Demeyer, 1977), and increased dietary protein reaching the abomasum in vivo (Poos et al. 1979). It also led to higher urea concentrations in the rumen of sheep fed on a protein-free diet, indicating decreased urease activity (Van Nevel \& Demeyer, 1979). Both of these properties would be potentially $\mathrm{N}$-sparing in the ruminant. In Rusitec, urease, induced by urea added to the vessels, was unaffected by monensin (Table 8 ), and proteolytic activity actually increased in vessels receiving monensin (Table 9). However, the output of $\alpha-\mathrm{NH}_{2} \mathrm{~N}$ was increased (Table 6) despite a slightly decreased total microbial output (Table 5), so it can be concluded that more dietary protein escaped degradation in the presence of monensin. As the analytical 
determination would also include free amino acids, it is possible that a decreased deaminative activity (not measured here) may be responsible for this effect (Van Nevel \& Demeyer, 1977; Horton, 1979; Chalupa, 1980; Chalupa et al. 1980). These factors led in turn to the assimilation of more non-protein $\mathbf{N}$ supplied as urea, such that protein output in vessels nos. 3 and 4 exceseded input (Table 6). Decreases in rumen $\mathbf{N H}_{3}$ concentrations sometimes seen with monensin (Dinius et al. 1976; Hanson \& Klopfenstein, 1979) may similarly be due to an improved capture of inorganic $\mathbf{N}$ and give rise to an improved efficiency of retention of diatary $\mathrm{N}$. Lower $\mathrm{NH}_{3}$ concentrations may also be a result of the suspected decreased deaminase activity in the presence of monensin.

The effects of monensin on the rumen fermentation are due to the different sensitivities to the drug of the various species of rumen micro-organisms. Monensin is most potent against Gram-positive bacteria (Haney \& Hoehn, 1967), and Chen \& Wolin (1979) found that among the rumen tacteria Ruminococcus albus, Ruminococcus flavefaciens and Butyrivibrio fibrisolvens (which although staining Gram-negative, has a Gram-positive cell wall structure; Cheng \& Costerton, 1977a) were most sensitive. Bacteroides ruminicola and Bacteroides succinogenes adapted to grow in the presence of monensin after $2-4 \mathrm{~d}$ and Selenomonas ruminantium was not affected to an antibiotic concentration of $40 \mu \mathrm{g} / \mathrm{ml}$. Chen \& Wolin (1979) compared this information with the known biochemical activities of these bacteria and concluded that monensin affected the fermentation by enriching for the less sensitive succinate and propionate producers. The effect on methanogenesis was, as predicted by Van Nevel \&: Demeyer (1977), not due to a direct inhibitory effect on methanogenic bacteria. Instead, monensin inhibited the growth of bacteria producing acetate, butyrate, formate and $\mathrm{H}_{2}$, leading to the diversion of metabolic $\mathrm{H}_{2}$ from methane production to propionate production.

Many of the results obtaired here with Rusitec support the ideas of Chen \& Wolin (1979). The microbial flora, although not changed in number (Table 4), as found also by Dinius et al. (1976) and Van Nevel \& Demeyer (1979), was of a different composition in monensin-treated vessels. Numbers of Gram-positive cocci decreased and more Gramnegative curved rods were observed, presumably the propionate-producing Selenomonas ruminantium. There was little difference in the numbers of ciliate protozoa at the lowest, physiological dose (Table 4), in agreement with the results of Dinius et al. (1976) and Jouany \& Senaud (1978). Monensir did affect the volume of protozoa (Jouany \& Senaud, 1978) and in Rusitec altered the composition of the ciliate population, as Polyplastron was eliminated from the vessels receiving monensin. Clearly, if the monensin concentration was increased, numbers of protcizoa were reduced (Table 4). This tendency is reflected in the decreases in protozoal numbers seen in lambs by Poos et al. (1979).

By altering the composition of the microbial population, monensin also changed some enzyme activities (Table 9). Succinate dehydrogenase activity was increased, consistent with the increased production of succinate and conversion of succinate to propionate predicted by Chen \& Wolin (1979). Similarly, acetate kinase activity fell in compartment no. 2, indicating a decreased number of acetate-prodicing, fibre-digesting organisms associated with the food. The increased specific activity of alkaline phosphatase in the presence of monensin (Table 9) indicates an increase in numbers of $B$. ruminicola (Cheng \& Costerton, $1977 b)$ and therefore corresponds well with Chen \& Wolin's (1979) observation that $B$. ruminicola adapts to grow in the presence of monensin. Monensin-induced changes in enzyme activity can be of therapeutic as well as nutritive value. The micro-organism which converts tryptophan to 3-methyl indole, the causative agent in acute bovine pulmonary oedema and emphysema, rnust be sensitive to monensin as the enzyme activity, and consequently the incidence of the condition, was abolished by monensin (Hammond $e t$ al. 1978). The distribution of enzyme activities (Table 9) also illustrates compartmentation of 
microbial populations in the rumen (Czerkawski, 1979) not only in the different specific activities of enzymes in the two compartments studied, but also in their susceptibility to monensin. Clearly, a different microbial population is associated with solid digesta compared with the free suspension, and the effect of monensin on these two compartments is therefore quite different.

The effect of monensin on cellulolysis and fibre digestion is not entirely clear, as these have been reported to be increased (Horton \& Stockdale, 1979), decreased (Poos et al. 1979; Slyter, 1979) or not significantly changed (Dinius et al. 1976; Lemenager et al. 1978) by the drug. Undoubtedly the effect depends upon the nature of the fibre and the dose of monensin. Monensin appears to inhibit degradation of the most resistant types of fibre (Oltjen et al. 1977; Coombe et al. 1979), and is not beneficial to animals on this type of diet, despite changes in the VFA pattern (Coombe et al. 1979). As the cellulolytic ruminococci are sensitive to monensin but $B$. succinogenes can adapt to grow in its presence (Chen \& Wolin, 1979), the effect on fibre digestion will depend on the relative roles of these classes of bacteria in the digestive activity. For the fibre in the food used in this experiment, it might be concluded that since it was the first $24 \mathrm{~h}$ phase which was mainly affected, the ruminococci carry out the early, more rapid fibre digestion while $B$. succinogenes digests the more resistant components.

Some difficulties experienced in the chemical analysis of samples taken from monensintreated vessels may also have been a symptom of a modified microbial population. The increased AEP in the effluent (Table 5) was possibly due to increased breakage of protozoa and the difficulty of removing microbial material from the food was probably associated with changes in the composition of the adherent microbial flora.

The effects of monensin can be divided into three periods, which for convenience may be termed the acute, the adapted and the resistant phases. In the acute phase, usually investigated by the addition of monensin to rumen fluid in vitro, growth of sensitive bacteria will be arrested, but they and their biochemical activities will not be removed and there will be no replacement of these bacteria by naturally monensin-resistant and adaptively resistant micro-organisms. This phase therefore has limited relevance to practical feeding and may give different conclusions from a long-term experiment. Following the acute phase, a new ecosystem is established, consisting of insensitive organisms and those such as $B$. ruminicola which adapt to grow in the presence of monensin (Chen \& Wolin, 1979). Monensin-sensitive micro-organisms will have been replaced or be present in much lower numbers than before. There may then follow a period in which organisms previously sensitive to monensin, such as the ruminococci, mutate to become more resistant to the drug, or alternatively other, monensin-resistant micro-organisms may be acquired to fill the same ecological niche. Acquisition of resistance in this way may account for the gradual drift in methane (Fig. 3 ) and acetate (Fig. 4) production in Rusitec towards the levels found in the control vessel. No drift was seen with digestibility (Fig. 1) or microbial yields but, given time, the same would probably occur with these factors, and monensin would cease to be effective, as may have occurred in the experiments of Poos et al. (1979) where monensin eventually ceased to affect digestibility. Drift also occurred in vessel no. 1, particularly in the stoichiometry of the fermentation products (Figs. 2-4). It seems unlikely that this resulted from contamination from the other vessels, as vessel no. 1 was always serviced before the others.

Recently, the results of some work with monensin in Rusitec have been published (Stanier \& Davies, 1980). These are broadly similar to our present findings, in that acetate, butyrate and methane production were diminished, while propionate was enhanced. The digestion of hexose was also decreased, in good agreement with the decreased digestibilities reported here. Output of microbial matter, however, was determined in the effluent only, and appeared to be decreased by monensin at normal dilution rates, in contrast with the results 
presented here (Table 5, 7). Since much of the microbial matter is associated with the undigested food (Table 5), this material cannot be ignored when estimating microbial yields. Thus, the exceptionally lo'w yields obtained by Stanier \& Davies (1981) (see review by Czerkawski, 1978) may be due mainly to underestimation of microbial matter. The lower yields at low dilution rate would be consistent with this conclusion, since sequestration of micro-organisms is known to be increased at lower dilution rates (Czerkawski \& Breckenridge, 1977b). It is therefore difficult to compare microbial yields from the different experiments.

In conclusion, the effects of monensin on Rusitec indicated a considerable shift in the microbial ecosystem. As a result, changes in the rate of fibre digestion and economies in the conservation of energy and nitrogen would occur in the ruminant receiving monensin. These economies would be expected to persist for a considerable period of time, but would gradually be reduced as bacteria became resistant to monensin.

The authors are grateful to Mrs C. Faulds and Mrs A. C. Fraser for their skilled assistance.

\section{REFERENCES}

Allen, J. D. \& Harrison, D. G. (1979). Proc. Nutr. Soc. 38, 32A.

Baile. C. A., McLaughlin C. L., P'otter, E. L. \& Chalupa, W. (1979). J. Anim. Sci. 48, 1501.

Baldwin, R. L. \& Palmquist, D. L. (1965), Appl. Microbiol. 13, 194.

Blaxter, K. L. \& Wainman, F. W. (1964). J. agric. Sci., Camb. 63, 113.

Chalupa, W. (1980). In Digestive Physiology and Metabolism in Ruminants, p. 325 [Y. Ruckebusch and P. Thivend, editors]. Lancaster, England: MTP Press Ltd.

Chalupa, W., Corbett, W. \& Bre:hour, J. R. (1980). J. Anim. Sci. 51, 170.

Chen, M. \& Wolin, M. J. (1979). Appl. environ. Microbiol. 38, 72.

Cheng, K.-J., Bailey, C. B., Wallace, R. J., Czerkawski, J. W., \& Costerton, J. W. (1979). Report of 15 th Conference on Rumen Function. Chicago, INov. 28-29, 1979.

Cheng, K.-J. \& Costerton, J. W. (1977a). J. Bacteriol. 129, 1506.

Cheng, K.-J. \& Costerton, J. W. (1977b). Appl. environ. Microbiol. 34, 586.

Cook, A. R. (1976). J. gen Microbiol. 92, 32.

Coombe, J. B., Dinius, D. A., Guering, H. K. \& Oltjen, R. R. (1979). J. Anim. Sci, 48, 1223.

Czerkawski, J. W. (1978). J. Dairy Sci. 61, 1261.

Czerkawski, J. W. (1979). Compartmentation in the rumen. The Hannah Research Institute Report pp. 69-85. Ayr, Scotland, KA6 5HL.

Czerkawski, J. W. \& Breckenridge, G. (1977). Br. J. Nutr. 38, 371.

Czerkawski, J. W. \& Breckenridge, G. (1979a). Br. J. Nutr. 42, 217.

Czerkawski, J. W. \& Breckenridge, G. (1979b). Br. J. Nutr. 42, 229.

Czerkawski, J. W., Christie, W. W., Breckenridge, G. \& Hunter, M. L. (1975). Br. J. Nutr. 34, 25.

Dartt, R. M., Boling, J. A. \& Bredley, N. W. (1978). J. Anim. Sci. 46, 345.

Demeyer, D. I. \& Van Nevel, C. J. (1979). Br. J. Nutr. 42, 515.

Dinius, D. A., Simpson, M. E. \& Marsh, P. B. (1976). J. Anim. Sci. 42, 229.

Dinsdale, D., Cheng, K.-J., Wallice, R. J. \& Goodlad, R. A. (1980). Appl. environ. Microbiol. 39, 1059.

Fitzgerald, P. R. \& Mansfield, M E. (1978). Am. J. vet. Res. 39, 7.

Hammond, A. C., Carlson, J. R. \& Breeze, R. G. (1978). Science 201, 153.

Haney, M. E. \& Hoehn, M. M. (1967). Antimicrob. Agents Chemother. p. 349.

Hanson, T. L. \& Klopfenstein, T. (1979). J. Anim. Sci. 48, 474.

Horton, G. M. J. (1979). Ann. Rèch. vét. 10, 335.

Horton, G. M. J. \& Stockdale, P. H. G. (1979). Am. J. vet. Res. $40,966$.

Hungate, R. E. (1966). The Rumen and its Microbes. New York and London: Academic Press.

Jarvis, B. D. W. (1968). Appl. Microbiol. 16, 714.

Jouany, J. P. \& Senaud, J. (1978ı. Ann. Zootech. 27, 61.

Joyner, A. E., Brown, L. J., Fogg, T. J. \& Rossi, R. T. (1979). J. Anim. Sci. 48, 1065.

Lemenager, R. P., Owens, F. N., Shockey, B. J., Lusby, K. S. \& Totusek, R. (1978). J. Anim. Sci. 47, 255.

Leng, R. A., Steel, J. W. \& Luick., J. R. (1967). Biochem. J. 103, 785.

McDougall, E. I. (1948). Biochem. J. 43, 99.

Nockels, C. F., Jackson, D. W. \&: Berry, B. W. (1978). J. Anim. Sci. 47, 788.

Oltjen, R. R., Dinius, D. A. \& Goering, H. K. (1977). J. Anim. Sci. 45, 1442.

Ørskov, E. R., Grubb, D. A., Smith, J. S., Webster, A. J. F. \& Corrigall, W. (1979). Br. J. Nutr. $41,541$.

Poos, M. I., Hanson, T. L. \& Klcppenstein, T. J. (1979). J. Anim. Sci. 48, 1516. 
Raun, A. P., Cooley, C. O., Potter, E. L., Rathmacher, R. P. \& Richardson, L. F. (1976). J. Anim. Sci, 43, 670. Richardson, L. F., Raun, A. P., Potter, E. L., Cooley, C. O. \& Rathmacher, R. P. (1976). J. Anim. Sci. $43,657$. Rose, I. A., Grunberg-Manago, M., Korey, S. R. \& Ochoa, S. (1954). J. biol. Chem. $211,737$.

Slyter, L. L. (1979). Appl. environ. Microbiol. 37, 283.

Stanier, G. \& Davies, A. (1981). Br. J. Nutr. 45, 567.

Thornton, J. H., Owens, F. N., Lemenager, R. P. \& Totusek, R. (1976). J. Anim. Sci. 43, 336.

Utley, P. R., Newton, G. L., Wilson, D. M. \& McCormick, W. C. (1977). J. Anim. Sci. 45, 154.

Van Nevel, C. J. \& Demeyer, D. I. (1977). Appl. environ. Microbiol. 34, 251.

Van Nevel, C. J. \& Demeyer, D. I. (1979). Ann. Rech. vét. 10, 338.

Wallace, R. J. (1979). J. appl. Bacteriol. 47, 443.

Wallace, R. J., Cheng, K.-J. \& Czerkawski, J. W. (1980). Appl. environ. Microbiol. 40, 672. 